\title{
La Chanson de Roland, Edition critique par Cesare Segre
}

\section{Walter Meliga}

\section{(2) OpenEdition}

1 Journals

\section{Edizione digitale}

URL: https://journals.openedition.org/studifrancesi/38868

DOI: 10.4000/studifrancesi.38868

ISSN: 2421-5856

\section{Editore}

Rosenberg \& Sellier

\section{Edizione cartacea}

Data di pubblicazione: 1 décembre 2004

Paginazione: 330

ISSN: 0039-2944

\section{Notizia bibliografica digitale}

Walter Meliga, «La Chanson de Roland, Edition critique par Cesare Segre», Studi Francesi [Online], 143

(XLVIII | II) | 2004, online dal 30 novembre 2015, consultato il 19 mai 2021. URL: http://

journals.openedition.org/studifrancesi/38868; DOI: https://doi.org/10.4000/studifrancesi.38868

Questo documento è stato generato automaticamente il 19 mai 2021.

\section{(c) $($ i) $(9)$}

Studi Francesi è distribuita con Licenza Creative Commons Attribuzione - Non commerciale - Non opere derivate 4.0 Internazionale. 


\title{
La Chanson de Roland, Edition critique par Cesare Segre
}

\author{
Walter Meliga
}

\section{NOTIZIA}

La Chanson de Roland, Edition critique par CESARE SEGRE, Nouvelle édition refondue, Traduite de l'italien par MADELEINE TYSSENS, Introduction, texte critique, variantes de 0 , index des noms propres, Glossaire établi par BERNARD GUIDOT, Genève ("Textes littéraires français", 968), Droz, 2003, pp. 391.

1 Riedizione del tomo I dell'edizione 1989 in due tomi presso lo stesso editore ("Textes littéraires français", 368; su cui cfr. SF, XXXIV, 101, p. 282), con l'aggiunta di un glossario (selettivo per le voci più frequenti) fondato sulle più note (come la celebre di Joseph Bédier) o recenti edizioni commentate e tradotte francesi. Si tratta di un volume utile, specialmente per l'insegnamento universitario. 